\title{
'No Boots on the Ground': Reflections on the US Drone Campaign through Virtuous War and STS Theories
}

\author{
Alcides Eduardo dos Reis Peron* \\ Rafael de Brito Dias**
}

\begin{abstract}
Since 2004, the US Air Force (USAF) and the Central Intelligence Agency (CIA) have persecuted insurgents in Somalia, Yemen and Pakistan with armed drones. Despite its alleged efficiency, this practice has been widely criticised on the grounds that it contravenes international humanitarian law. In order to understand the controversies involving this practice, we examine how this new technology was linked to and allowed the emergence of a new US international security strategy first applied in the Middle East. Drawing on James Der Derian's post-structuralist theories about virtuous wars, the sociotechnical approach allowed by Science and Technology Studies (STS), and Gregoire Chamayou's theories about drones, we argue that the US intention in adopting these technologies was not to enhance its military capability but to allow the USA to remain active in several risky theatres while avoiding the political and social costs of conventional military engagement.
\end{abstract}

Keywords: Drones; Media; Virtuous War; Post-Structuralism; Social Studies of Science and Technology.

\section{Introduction}

Since the spread of the Islamic State of Iraq and the Levant (ISIL) in the Middle East, which destabilised the fragile order created by the North American interventions in Iraq and Afghanistan, the USA has been expected to continue acting against it. This has complicated its strategy of military disengagement from the region adopted by the Obama administration. Despite the withdrawal from Iraq in 2011, a significant reduction of troops in Afghanistan, and a reduction in support for the forces combating ISIL in Syria, the USA has been unable to withdraw entirely from violent conflicts in the Middle East.

\footnotetext{
* University of Campinas (Unicamp), Campinas-SP, Brazil; dudperon@gmail.com. ORCID iD 0000-00034537-2775.

** University of Campinas (Unicamp), Campinas-SP, Brazil; rafael.dias@fca.unicamp.br. ORCID iD 00000002-9702-2323.
} 
In a recent article in USA Today, Korte (2015) pointed that, in the last two years of his presidency, Barack Obama repeated the expression 'no boots on the ground in Syria' some 16 times. In each instance, Obama emphasised that remaining forms of engagement would be limited and proportional. However, this has masked the emergence of a highly significant development, namely military engagement without the deployment of troops.

This strategy involves new technology developed by the USAF in the form of the Predator MQ-9 Drone. Following the alleged success of drone strikes in Pakistan, the USA is deploying this weapon throughout the Middle East, thereby lowering its profile in the region while avoiding adverse domestic responses to deaths in combat.

The main risks associated with traditional military campaigns against 'terrorist' movements in other countries are the deaths of American soldiers, as well as massive costs. In an effort to differentiate the imaginary of a long-term operation from extrajudicial killings by means of drones in the Middle East, Obama has linked this new strategy to a mere issue of reducing political risks:

The question for the American people is, is that a responsibility that we'll be willing to bear? And I believe that when you have a limited, proportional strike like this - not Iraq, not putting boots on the ground; not some long, drawn-out affair; not without any risks, but with manageable risks - that we should be willing to bear that responsibility (Obama, quoted in Korte 2015).

This resembles the strategy previously adopted in Serbia when, fearful of an escalation of violence in the Balkans, but also of the costs of inaction, then US president Bill Clinton resorted to an aerial bombing campaign. By contrast, the current strategy amounts to a reluctant techno-political engagement that minimises the political risks of engagement. However, as Riza (2013) points out, both strategies have resulted in many unjustifiable civilian deaths. O'Connell (2011) argues that numerous juridical, ethical and political issues need to be considered in order to judge the 'efficacy' of this strategy.

In this context, we intend to discuss the reasons for the US decision to resort to drone strikes in the Middle East and Northern Africa, and their major implications. We argue that, while the use of drones in military and covert operations is far cheaper than conventional military interventions, the real intention behind the employment of drones is to avoid the political and social consequences of keeping 'boots on the ground. We also argue that resorting to easier forms of projecting power has been a growing trend in US military strategy for the past 20 years.

We do not intend to delve too deeply into the theoretical discussions developed by James Der Derian and Gregoire Chamayou on virtuous wars and the critical theory of armaments. Our idea is simply to draw on those discussions in unpacking issues around the use of drones, including its ability to 'sanitise' manhunts and media coverage, and feed supportive official discourses. Viewed in this way, the use of drones is the latest version of an ongoing US techno-strategy to remain engaged with foreign conflicts while cushioning the American public against the destructiveness and illegalities of war. In doing 
so, we will discuss various approaches to international conflicts involving relationships between technology and politics, and how this brings up new facts, trends and problems for discussion.

We will initially discuss the theories of Der Derian (2009b) and Chamayou (2013), demonstrating how they link science, technology and society. In the second section, we will examine recent US engagements in the Middle East, describing how the deployment of drones and a 'virtuous' discourse provided Washington with a 'mid-term' solution. In the third section, we will discuss the determinants of the so-called Revolution in Military Affairs (RMA), the contextual genesis of the Predator Drone, and how this led to the design of unmanned aerial systems and the controversial dynamics of their employment.

\section{Virtuous war theory and the theory of the drone: remote operations and the rupture of reciprocity}

Following the end of the Cold War, positivism and structuralism faced a crisis of methodology and legitimacy. Even with the support of the hard sciences in developing methods of behavioural prediction, they had failed to predict the outcome of the bipolar world order. Moreover, traditional theories and methods were unable to describe, diagnose and propose remedies for many new issues - including terrorism, migration, technology, and financial flows - that entered the realm of security (Buzan and Hansen 2009).

This turmoil in the social sciences soon reached the shores of International Relations, stimulating new critical perspectives and positions. The new theorists included poststructuralists, who - inspired by the so-called crisis of modernity and its interpretations in philosophy and sociology - have played a major role in describing and analysing complex news sets of relations and phenomena in the contemporary world. As Der Derian (1988: 192) notes, post-structuralism has emerged as a means of deconstructing notions of knowledge and science, and challenging the assumptions of the structuralist discourse. Post-structuralist critics view international reality as a scientific discourse that produces 'regimes of truth' about what should and should not be recognised as legitimate knowledge in International Relations (Resende 2011: 20). As Resende (2011) points out, members of this school of thought are worried about the consequences of modernity, the lack of freedom derived from the disciplining of individuals, and the naturalisation of the state as a privileged actor in the political organisation of collectivities.

Although post-structuralism is extremely influential in International Relations, few authors have sought to analyse the role of the media and technology in the dynamics of violent conflict. We will concentrate on two authors: Der Derian, with his constructivist and critical approach to modern warfare, and Chamayou, with his notions around the genealogy of manhunts and the employment of drones. Both place technology at the centre of strategies of international security, and seek to identify the social and political implications of the technical mediation and media representation of recent conflicts.

Criticising the notion of linear technical progress in warfare, and supporting the idea of heteropolarity in the international system (as manifested by the emergency of new non- 
state actors, such as media complexes, in shaping international policies), Der Derian observes particularities in the way in which the USA fights its wars and employs technology. He argues that contemporary conflicts conducted by the USA should be understood as Virtuous Wars, in the sense that both the representations of those conflicts in the mass media and government discourse, as well as new technologies of warfare, create a kind of moral distancing from the war. While these technologies allow the physical distancing of combatants from the battle, they also mediate this relation through several interfaces and systems. Media and government together help to create and disseminate a representation of light and surgical war.

War becomes virtual - with action separated from physical presence - as well as virtuous, given the way in which it allows the media and government to build a positive, tolerable, and 'drama-free' representation of the conflict. Considering the status of the USA as the 'deus ex machina' of global politics, with its diplomatic and military policies increasingly based on technological and representational forms of discipline, deterrence and compulsion, Der Derian argues that there is no better term for defining this new form of organised violence:

At the cyborg heart of virtuous war is the technical capability and ethical imperative to threaten and, if necessary, actualize violence from a distance with virtually no casualties. [...] On the surface, virtuous war cleans up the discourse of conflict. Fought in the same manner as they are represented, by real-time surveillance and TV 'live feeds', virtuous war promote a vision of bloodless, humanitarian, hygienic wars (Der Derian 2009a: 241-244).

In this view, the use of sophisticated communication and information technologies as instruments of war, as well as the relationship between the media, the military and the government, represent violent conflicts in their most aseptic dimension, eliminating any sign of an undesired reality. The USA has used this strategy to guarantee the moral legitimacy of its involvement in various conflicts since the Gulf War. However, the research developed by Der Derian is based on a genealogical understanding and mapping of the discourses, practices, institutions and technologies comprising the core of the Virtuous War, the 'Military-Industrial Media-Entertainment Network' (MIME-Net).

His research, including attendance of military congresses, interviews with authorities, and studies of military documents, media narratives about conflicts, and new technology, has led him to denounce not only the emergence of an 'aesthetic' discourse of contemporary conflicts, but also the informal development of the MIME-Net. According to Der Derian, this network consists of media corporations, simulation and video games industries, military colleges and institutions, and think-tanks, aimed at connecting and promoting their interests, but mainly to dissimulate manipulated, decontextualised, misinformed or dissimulated views and narratives of conflicts. This controlled image of conflicts comprises an 'Informational War', 'a weapon of destruction as well as persuasion and distraction' (Der Derian 2009b: 277-278). This collective unconsciousness or distancing is the 
sine qua non for the perpetuation of conflicts without any form of contest or intolerance of the destruction.

Chamayou (2013: 24) sustains a critical approach to war instruments which allows an understanding of how the means constrain the forms of action, affecting both users and targets. According to him, the only way to dismantle the 'military fight mechanism' is to expose the hidden patterns of power and authority in technology. Rather than questioning whether the ends justify the means, he argues that it is much more important to understand the implications of the choice of means for the actors. Given this, he suggests that the employment of drones has significant consequences for the comprehension of war and of organised violence.

Chamayou's notion of the elimination of reciprocity in the course of drone campaigns is central to understanding the implications of drones for war, politics and strategy. This happens because the drone operators - more so than the decision-makers, as we argue later - no longer have to face the physical consequences of their actions. Removed from the sites of conflict by computer screens and the rest of the sociotechnical apparatus, they are protected against counterstrikes and removed from the horrors of destruction.

In Chamayou's analysis, the fact that these instruments allow the prolongation and radicalisation of existing procedures of distanced wars result in the elimination of the combat itself. The elimination of reciprocity changes the very nature of war, which is the dispute between forces that could be unequal, but with the equal intention of conquering each other on the battlefield. The employment of drones in preemptive conflicts eliminates the chance of a dispute between the parties, reducing it to a 'manhunt' dialectic between predator and prey, where the former hunts and seeks, and the latter can only run and hide (Chamayou 2013: 49-50).

Chamayou's notion of a manhunt is not incidental but related to George W. Bush's characterisation of the 'Global War on Terror' as a kind of global manhunt, demonstrating a new paradox in the employment of violence: the idea of surgical interventions that do not affect and are not visible to general populations. This 'cynegetic power' is not aimed only at eliminating the adversaries, but at keeping them in constant fear, dominated, prostrated, and sometimes only excluded.

Whenever Chamayou and Der Derian focus on the impact of technology on military strategy and political thought, they draw closer to the perspectives of Science, Technology and Society (STS). They not only question the power and hegemony of scientific methods but also of technology, exploring how technology influences and is influenced by society. Rooted in social constructivism, these studies have gained momentum over the past four decades. While methodologically and analytically diverse, they assume that both technology and science are social products, built and developed in certain political and social contexts, and shaped by certain values and interests.

For the purposes of this study, we will concentrate on the rejection of 'technological somnambulism' by Langdon Winner (1986). According to Winner, technological somnambulism is a perception in the social sciences that technologies are neutral objects, with no relevant past or social determination, and no significant influence over life and society. 
In his view, technology and technical artifacts carry not only history but mainly politics, which means that technology provides convenient means of establishing patterns of power and authority in determinate contexts. Consequently, in several cases, some forms of technology are strongly and inevitably connected to particular institutional patterns of power and authority (Winner 1986: 16).

The connection between Chamayou, Der Derian and STS allows us to understand the major role of technology - especially drones - in the making of recent US security strategy for the Middle East. In this context, the analytical categories in this approach - distancing, disrupted reciprocity, and the manhunt logic - reveals the very essence of the US drone campaign: utilising technical solutions to circumvent the political limits on American military operations in the Middle East.

Distancing and disrupted reciprocity have similar effects, and operate on physical, moral and perceptual levels, allowing a complete disconnect between society and conflict, combatant and battlefield, intervention and political costs. Whenever these new technologies favour the distancing and administration of conflicts from afar, thereby helping to regulate the flow of information from and over those conflicts, 'hearts and minds' are induced to tolerate dubious interventions and practices.

The strategy of employing drones allows the USA to move ahead with policing and military practices without any form of expressive or popular questioning. Constructing extrajudicial killing as legitimate practice and covering up the results of its tactics is the essence of a Virtuous War, a way of projecting power while dodging national public opinion and the international legal and political order. This strategy creates new dilemmas around the effectiveness of remotely conducted operations and the preservation of the integrity of civilians which are far from being resolved, but also off the agenda.

\section{The contemporary security dilemma in the Middle East: opening doors for surgical discourse}

From the outset, Obama faced internal and external pressures to end American military involvement in the Middle East. The 'Global War on Terror', particularly the invasions of Afghanistan and Iraq, were widely criticised, both nationally and internationally, and progressively burdened the US national budget. At the same time, military commanders, intelligence officers and local political role players emphasised the multiple risks associated with an abrupt or total withdrawal.

While Obama faced growing budgetary issues and criticisms of US involvement in the Middle East on the one hand, he remained under pressure from specialists and other governments to continue America's military involvement in the region on the other. Given this, how could military operations be continued without having to deal with its political, economic and social implications?

In December 2014, Amy Belasco, a specialist in Defence Policy and Budgeting, wrote a report to Congress in which she analysed the US\$ 1.6 trillion spent on military opera- 
tions during the previous 13 years. Of this, 43\% was spent in Afghanistan, $51 \%$ in Iraq, and $7 \%$ on other war-related expenses (Belasco 2014).

Following the financial crisis in 2008, it was natural for senators and congressional representatives to become less willing to authorise military expenditure. Added to this, many of them began to criticise and oppose seemingly permanent American involvement in the region, raising the costs and political risks of long-term campaigns. As a result, during his second term of office, Obama authorised a mass withdrawal from Iraq up to 2011, and then from Afghanistan up to 2017. According to the Belasco report, this reduced the military budget considerably, but from 2015 onwards the rate of reduction slowed down due to aerial strikes against ISIL in Syria and Iraq. From 2010 to 2015, military spending fell from 4,6\% of GDP to 3,3\% (Belasco 2014).

However, this never meant that the USA would terminate its military presence in the region. Figure 1 shows that from 2008 to 2015 there were more than 580 American drone strikes in Pakistan, Yemen and Somalia, demonstrating that they had become a key feature of the US strategy for fighting insurgents abroad. But why did this strategy become a dominant trend during the Obama administration?

Figure 1: US drone strikes in Pakistan, Somalia and Yemen, 2008-2015

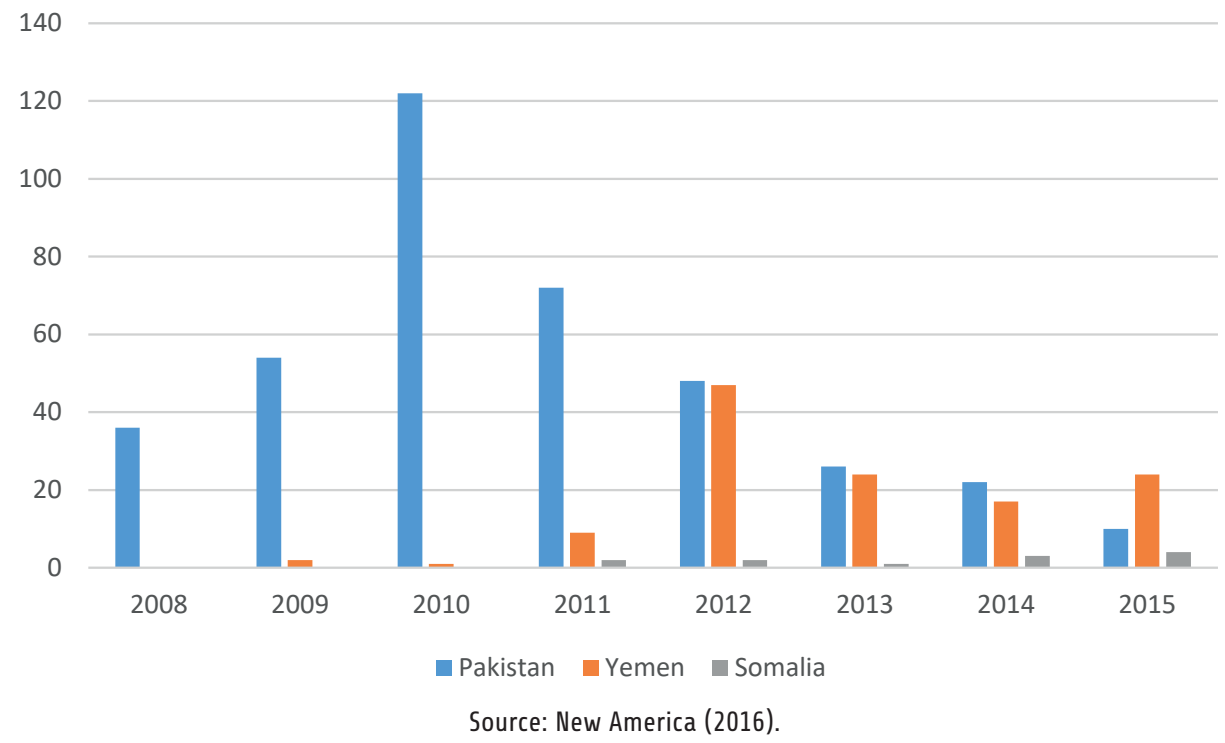

The reasons were economic as well as political. According to Hall and Conye (2013), from 2000 to 2013 the US investment in drones increased from US $\$ 362 \mathrm{~m}$ to US $\$ 2,9$ billion. As a result, the US drone fleet has expanded from 50 in 2000 to some 7000 today, representing more than a third of the aircraft in the USAF.

The Reaper-MQ-9 costs about US\$6.48m, almost US\$3m a year to operate, and about US $\$ 3250$ per hour of flight. Flying one drone requires a large infrastructure of satellites, cables, and about 185 personnel. By contrast, a F-35 Joint Strike Fighter costs about US $\$ 91 \mathrm{~m}$, about US $\$ 5 \mathrm{~m}$ a year to fly, and US $\$ 16000$ per hour of flight (DoD 2010). More- 
over, according to Harrison (2013), deploying a single solder in Afghanistan in 2012 cost no less than US\$2,1m a year, excluding possible medical care and rehabilitation.

These financial considerations began to push politicians and the military towards a more economical presence in the region. In 2012, the Secretary of Defense, Leon Panneta, advocated a reduction of troops in Middle East while proposing an increase in surveillance and attack drones and Special Operations Forces (DoD 2012). And the 2010 Defense Review stated that the employment of unmanned drones formed part of a successful strategy of counterterrorism and counterinsurgency, and would remain a priority until 2015. In 2012 the Pentagon asked Congress for nearly US $\$ 5$ billion for the further development of drone systems.

Technical and political motivations also played a role. In his speeches between 2010 and 2014, Obama emphasised the efficiency and surgical precision of drones, rather than their lower costs, in what could be described as a search for a 'surgical legitimacy'. In a speech at the National Defense University in 2013, he declared:

To begin with, our actions are effective. Don't take my word for it. In the intelligence gathered at bin Laden's compound, we found that he wrote, 'We could lose the reserves to enemy's air strikes. We cannot fight air strikes with explosives.' Other communications from al Qaeda operatives confirm this as well. [...] Simply put, these strikes have saved lives (Obama 2013).

Through this kind of discourse, the US government sought to legitimise the use of drones for dealing with insurgents abroad instead of mobilising troops by extolling their virtues and performance. This had favourable political and social consequences. To understand this, one has to recall that 'targeted' and 'signature' strikes are conducted by operators from US territory, with no risk to their physical integrity. Moreover, the fact that this tactic is extremely precise, stealthy, and capable of identifying and eliminating individuals or small group of individuals, supposedly without collateral effects, plays an important political and social role.

Given this, drones came to be presented as 'the only game in town' (CIA 2009) for combating insurgents and terrorists in turbulent regions and in politically and physically risky situations where the integrity of the combatants and the military incursion might otherwise be at stake. Moreover, while they are controlled from long distances away, their efficacy is assured by their extremely precise cameras, infrared sensors, smart missiles, and stealth, among others. In this discourse, in which the drone is constructed as a surgical, risk-free and effective weapon for combating terrorism, the US public increasingly accepted its employment as moral and legal. This discourse held the clear message that contemporary conflicts in the Middle East was addressed by the responsible employment of surgical weapons than by costly and risky troop mobilisation and the use of major weapons systems.

As both Plotnick (2012) and Riopelle and Muniandy (2013) point out, this 'enchanted' vision of drones is not only sustained in the official discourse but also in the mass media, thus working as a vector for the Pentagon and government discourse. According to Plot- 
nick, in the 1990s and in the immediate aftermath of 09/11, the American mass media revived the ideal of autonomous, rational and lean war through the myth of 'push-button warfare'. Although she shows that the treatment of this idea was not homogeneous over time (sometimes the media were more skeptical, and sometimes more enthusiastic), she has effectively revealed the importance of this theme.

Riopelle and Muniandy argue that both the official and media discourses about the 'War on Terror' and the use of drones are sustained as an aestheticised and disembodied fantasy. Based on an analysis of graphic representations of the Middle East, the authors show that the media - particularly CBS News - construct an imagined and exceptional enemy place, depicting the region as uncivilised and violent. On the other hand, drones are represented as an aesthetic and lean instrument, thus helping to legitimise the preemptive US actions in the region (Riopelle and Muniandy 2013: 170).

Two examples corroborate the argument that the media are disseminating and naturalising the official discourse on the employment of drones. On 2 and 4 September 2012 respectively, Reuters and CNN carried articles about the same US drone strike in Yemen that killed several people. The title of the first article already stated that 'five suspected militants' had been eliminated, and that they were 'connected to Al-Qaeda'. Adopting the point of view of the interviewed officer, Reuters described the victims as 'Islamists', killed because they were in a vehicle that was 'believed to carry militants'. Even the officer acknowledged implicitly that there was no certainty about the nature and 'guilt' of the people who were killed. 'Five were killed and eight injured, and we are still investigating who these men are and in what way they were linked to Al-Qaeda' (Reuters 2012).

Two days after its first report, CNN International reported that 13 civilians - including three women - had been killed. This report included statements by Yemenite officials that they regarded the attack as an 'immense mistake' (Almasmari 2012).

These reports show not only that these attacks may be inaccurate, but also expose how the mass media seek to legitimise them by reproducing a savage representation of the Middle East. A report commissioned by the law departments of NYU and Stanford University and published in 2012 also criticised the reproduction by the mass media of the same categorisation employed by the armed forces to describe those killed in the strikes as 'militants' and 'civilians', arguing that this tends to reinforce the notion that every strike against militants is a legal and precise act (International 2012). In an article written for The Guardian in 2014, Ackerman revealed that more than one attack was often necessary to eliminate a specific target, thereby increasing the number of victims. For example, the killing of Baitullah Mehsud, leader of the jihadist organisation Tehreek-e-Taliban Pakistan (TTP), required more than seven strikes, during which 164 people were killed. However, this attracted almost no media interest (Ackerman 2014).

A Gallup poll conducted in the USA in 2013 showed that about $65 \%$ of respondents supported drone strikes in other countries against suspected terrorists. About half (49\%) closely followed the news about drones and drone strikes, and of these, $74 \%$ were more likely to support drone strikes against suspected terrorists overseas (Brown and Newport 2013). This shows not only that a majority of people began to support drone strikes, but that those who did were absorbing the discourse produced by the mass media. This shows, 
in turn, that the media had become a vector for the official discourse about American military operations in the Middle East, evincing a complex relationship between the means of communication, conflicts, and the military.

The use of drones in contemporary conflicts is justified not only because they cost less, but also because they reduce the political risks of remaining active in the region in question. The possibility of waging a conflict remotely, thereby greatly reducing its costs and political risks, has played a major role in the ability of the USA to sustain its military presence in various world regions. It amounts to a virtuous strategy, conducted remotely and without a physical presence, which allows its depiction in the media as a 'new normality' while sustaining a state of permanent violence. Essentially, this form of violence is perpetrated in constant and small doses against named individuals, which perfectly matches Chamayou's notion of cynegetic power in which fear and harassment play a key role in American dominance over the region. ${ }^{1}$

\section{The Revolution in Military Affairs and the development of the Predator MQ-1}

Why interrogate these practices when they are supposedly cheap, efficient, and decreasing in frequency? While Figure 1 reflects a significant reduction in the number of drone strikes in Pakistan, it reflects an increase in strikes in Yemen and Somalia since Obama took office in 2009.

From 2007 to 2011, there were 10 drone strikes in Yemen, an average of two a year, while from 2012 to 2016 there were 121 strikes, an average of 24,2 a year. From 2005 to 2010 , there were no drone strikes in Somalia, and only 10 ground raids and cruise missiles launches, while from 2011 to 2016, 72,4\% of total strikes were performed by drones (New America 2016).

Moreover, even though the first air strikes against ISIS by the US-led coalition were carried out by jets and bombers, with drones playing a minor role, costs played a growing role in favouring the latter. According to the DoD (2017), since the start of these operations in August 2014 until early 2017, there were 24566 air strikes in Syria and Iraq against ISIS positions, of which $76 \%$ were conducted by the USA at an average daily cost of US $\$ 13,6 \mathrm{~m}$, and a total cost of more than US $\$ 14,3$ billion.

As the number of drone strikes rose, so did the number of non-combatants or nonmilitants killed in the strikes. Table 1 records the victims of drone strikes in Somalia, Pakistan and Yemen from 2008 to 2015. It shows that an average of 1,68 civilians, children and 'unknown' people were killed per strike, and more than 1200 people were injured.

While the number of civilians, 'unknown' people and children killed as well as those injured may seem small relative to the number of 'alleged militants', two other studies reveal an alarming lack of precision. The first is an analysis by Zenko and Wolf (2016) who note that the 24848 bombs dropped from manned aircraft in Afghanistan from 2009 to 2015 killed 1214 civilians, which corresponds to one civilian per 21 bombs dropped. 
Given that the rate for drone strikes of one civilian per 1,6 strikes is far higher, this contradicts the idea that they are more precise than strikes from conventional aircraft.

Table 1: Victims of US drone strikes in Somalia, Pakistan and Yemen, 2008-2015

\begin{tabular}{llllllll}
\hline & Attacks & $\begin{array}{l}\text { Total } \\
\text { killed }\end{array}$ & $\begin{array}{l}\text { Alleged } \\
\text { militants }\end{array}$ & Civilian & Unknown & Injured & Children \\
\hline Pakistan & 402 & 3623 & 3030 & 315 & 278 & 1161 & 172 \\
Yemen & 148 & 1248 & 1103 & 93 & 52 & 94 & 8 \\
Somalia & 32 & 375 & 316 & 40 & 19 & 8 & 2 \\
Total & 582 & 5246 & 4449 & 448 & 349 & 1263 & 182 \\
\hline \multicolumn{7}{c}{ Source: New America (2016). }
\end{tabular}

While the number of civilians, 'unknown' people and children killed as well as those injured may seem small relative to the number of 'alleged militants', two other studies reveal an alarming lack of precision. The first is an analysis by Zenko and Wolf (2016) who note that the 24848 bombs dropped from manned aircraft in Afghanistan from 2009 to 2015 killed 1214 civilians, which corresponds to one civilian per 21 bombs dropped. Given that the rate for drone strikes of one civilian per 1,6 strikes is far higher, this contradicts the idea that they are more precise than strikes from conventional aircraft.

In a report published in 2010, a special UN rapporteur, Phillip Alston, argued that the USA did not provide enough information about deaths during drone strikes. The New America Foundation and the Bureau of Investigative Journalism have questioned the use of the term 'militant', mainly because the US authorities have acknowledged that people categorised in this way might be civilians involved in the hostilities. The International Committee of Red Cross has criticised any attempt to directly link 'civilians' with 'hostilities' (Melzer 2009: 4).

The development of the first armed drone, the Predator MQ-1, formed part of the Revolution in Military Affairs (RMA) in the 1980s and 1990s. The RMA is a radical doctrine for revolutionising the organisation of operations and procurement processes through the use of new technology. While it emerged during the Gorbachev administration in the former Soviet Union, it was soon adopted in the USA and elsewhere. The RMA in the USA began with the notion of 'Network-Centric Warfare' that developed in the military schools at that time. It involved a recognition that computer-based technologies could completely change the way in which military operations were conducted, among others by controlling war instruments at a distance.

Therefore, we need to examine the history of the development of the Predator, mainly because it reveals the actors and intentions behind this technological and strategic revolution, including the introduction of permanent surveillance and the ability to conduct strikes at a distance without having to deal with their political and social consequences. The development of the Predator in the context of the RMA shows that its effects of distancing and of rupturing reciprocity were predicted and intended. This becomes evident when we analyse the structural and technical problems faced by the CIA and USAF in the course of turning the Predator into a weapons platform. The discourse around the RMA 
was alluring, and chimed with the US intention to maintain its military dominance after the Cold War. Factors that played a role in the development of the Predator include:

i. A decrease of military expenditure on research and development (R\&D) after the end of the Cold War, leading to new arrangements between the Pentagon and its suppliers (Kaldor 1999).

ii. New threats, such as aggressive terrorist organisations, which tended to hinder the effectiveness of traditional forms of military intervention (US Army 2013).

iii. Domestic resistance to undertaking costly long-term conflicts, also known as the 'Vietnam Syndrome' (Herring 2012).

iv. The need to establish greater control over information flows about military interventions (Gray 1997), both in terms of media coverage and intelligence-gathering.

The RMA was structured as a series of organisational principles aimed at harmonising defence technologies and management, leading to a new way of organising military operations. Alongside changes in institutions, doctrines and culture, these innovations led to a veritable reordering of war. Many sought to restructure military doctrine and systems involved in the traditional 'Command and Control' chain. As noted by Bellamy (2001: 61), the idea was to develop a system that would allow the US Armed Forces to perform fast, small and decentralised operations as an ideal way of conducting 'irregular' and surgical forms of warfare.

Following the intensive use of satellite communications and devices for building interoperability', the Command and Control system was restructured into what became known as C4ISR (Command, Control, Computer Communication, Information, Surveillance and Reconnaissance). The main goal of $\mathrm{C}^{4} \mathrm{ISR}$ was to allow the command of surgical and remotely operated missions matching the doctrine of rapid dominance, such as Shock and Awe. This doctrine, sustained by the USA during the invasion of Iraq, is characterised by fast and surgical military action enabled by new technologies and systems (Ullman and Wade 1996).

The intention of the DoD was to conduct operations with devastating power but greater precision, combining 'innovative operational concepts' and advanced weapons systems in order to alter 'the way US forces conduct the full range of military operations' (DoD 1999). Operations could now be based on information-gathering and the scouting of enemy positions through a myriad of connected instruments that enabled distanced military action in a 'network-centric warfare', as envisioned by Admiral Arthur Cebrowsky (2000: 5). This sociotechnical reordering of the $\mathrm{C} \& \mathrm{C}$ system relies on improved surveillance and an awareness of the enemy's behaviour. In this sense, the use of drones as instruments of surveillance, and possibly as arms platforms, could contribute to the 'momentum' of the new C ${ }^{4}$ ISR system.

The story of the development of the Predator is one of controversy and the participation of several actors, including General Atomics and the USAF, but mainly the DoD and the CIA. It reveals the intention of these role players to circumvent the political limits to the 'war on terror', eliminating any form of reciprocity. This happened once the main 
institutions surrounding the DoD, the USAF and CIA, agreed that in order to combat terrorism they could not 'play by the normal rules', respecting the borders and sovereignty of the countries involved. Instead, from 9/11 onwards, drone strikes and many other interventions relied on the doctrine of preemptive war, which justifies the arrest and killing of people without trial.

In 1992, following the outbreak of the conflict in Bosnia and the NATO decision not to put troops on the ground, the idea of using drones gained momentum. As a result, the US Joint Chiefs of Staff asked the then director of intelligence, Michael Cramer, to develop a system that would allow drones to survey enemy positions without compromising the life of combatants. The director of the CIA, Jim Woolsey, participated actively in the process of contracting and development. At that time, the CIA and the US Navy became interested in the project and introduced several additional requirements, including the expansion of drones' remote operating capacity, which demanded a stronger radar system. As a result, General Atomics developed the extensively modified GNAT 75, which made less noise, and had more carrying capacity and flying autonomy (Whittle 2014).

In 1994, following the successful deployment of the GNAT in the Bosnian conflict, the Pentagon launched a programme for the further development of drones. With an initial budget of US $\$ 20$ million, 'Program Predator' belonged to the US Navy, and was aimed at producing a new drone based on existing technology in order to limit costs. The specifications were developed by the Navy and the CIA, and involved a redesign to carry $230 \mathrm{~kg}$ of equipment. This involved modifying the nose cone to accept new and stronger radar, and extending the wings to eight metres each to give it more altitude and stealth. Many other changes were made to this prototype, initially called Tier II and finally called Predator RQ-1, to suit it to its proposed role of surveillance and reconnaissance.

At this stage, the role of drones no longer centred on formal military battles - the Predator was being prepared for stealth surveillance over sovereign countries. When the DoD authorised the CIA and USAF to issue more specific requirements for the Predator project, its design and essence changed. This is when the Predator RQ-1 began to overcome its limited function of reconnaissance. According to Richard Whittle, both the USAF and the CIA wanted to start using drones to support troops on the ground, besides lone activities of surveillance and intelligence-gathering.

These intentions were clarified when the Clinton administration began to consolidate its strategy for combating terrorism, following a series of attacks on American buildings and embassies in 1996 commanded by al-Qaeda. Since the 'hallmark' of Clinton's administration was to promote security through economic development (amounting to investments in multilateral liberal peace), the role of combating these terrorist cells and organisations was delegated to the CIA. Given its knowledge of the risks of gathering intelligence on the ground, the CIA relied on the enhancement of the Predator as a means of watching al-Qaeda in Afghanistan and Pakistan.

As a result, the CIA altered the design of the Predator, and promoted structural changes in the command chain. Drones from Afghanistan could not be operated from any neighbouring country, as political considerations prevented them from harbouring US command centres. The solution was to change radio frequencies in such a way that 
the drones could be operated via satellite. Within a year, they were being operated from Ramstein in Germany.

While this allowed the USA to control the drones from Germany, and sustain operations such as that which identified large numbers of al-Qaeda members on Tarnak farm in Afghanistan in 2001, it was not sufficient. As recorded by both Richard Wittle (2014: 266) and Brian Williams (2010:33), the Secretary of Defense in the Bush administration, Donald Rumsfeld, and the Joint Special Operation Commanders were greatly frustrated when they spotted Osama bin Laden, the al-Qaeda High Council and General Mullah Omar in Afghanistan in the same year, but could do nothing about it as the rules of engagement did not authorise extrajudicial killings.

The push to arm the Predator only started after the terrorist attacks on the guided missile destroyer USS Cole in Yemen in October 2000 in which 17 American sailors were killed. Immediately after the attack, a small 'coalition' was formed, led by Major-General Michael Kostelnik, chief of the Air Armament Center; General John Jumper, head of the USAF; and George Tenet, director of the CIA. The coalition aimed at gaining permission for the Predator to perform airstrikes during war but also to undertake extrajudicial killings in sovereign countries. At that point, the CIA and USAF were concentrating on how to eliminate 'terrorists' or 'insurgents' without compromising the lives of combatants, or America's political and legal status.

The 'next logical step', in Jumper's account of arming the Predator, was not a simple one, mainly because the $\mathrm{DoD}$ was aware that kinetic attacks to eliminate insurgents abroad were very sensitive and even illegal. Therefore, the whole system had to be arranged in such a way that the operations would not produce any undesirable political and legal consequences. This confirms that both the CIA and the USAF were seeking technical ways to circumvent these limits.

One involved the kinds of armament the drones would use. The USAF needed to respect two criteria, one economic and the other political. The first was related to costs, dictating the use of a 'smart' missile that had already been developed, was relatively cheap to produce, and capable of surgical deployment. The second was that it should already have been evaluated by the Armed Forces in fulfilment of Article 36 of the Geneva Convention (United Nations 1979). The missile chosen was the AGM-114, or Hellfire, previously launched from helicopters, whose weight, design and cost were compatible with the dynamics of the Predator. But the decisive element, as Rogers and Hill (2014: 50-51) note, was that both the Predator and the Hellfire had been separately approved by the US Armed Forces and international commissions. This was a tactic adopted by the USAF and the CIA in order to gain approval of the armed drone as a whole, because even though the drone and the missile had not been evaluated together, they had already been approved separately for deployment in international conflicts.

The main juridical-political problem was the disposition of the drone operators. Until then, Germany had allowed the USA to use the Ramstein base for surveillance operations. However, it seemed clear that the German government would not allow airstrikes to be 
carried out from German territory. Among other things, performing dubious acts of war while based in another country could expose the operators to criminal charges.

This problem was resolved by moving the Ground Control Stations and Command Centres from Germany to the USA. This was achieved by retaining the TMET antenna systems at Ramstein, and connecting them via optical fibre to CIA headquarters at Langley in the USA. This was done in a few months and allowed the CIA and USAF to conduct extrajudicial killings from American soil, therefore avoiding criminal charges, or political constraints on its actions.

This shows how technology was used not only to improve the Predator itself, but also to address the economic, social and political problems and dynamics surrounding American military involvement in the Middle East and elsewhere. Persistent presence, surveillance and destruction could only be achieved if the operations were conducted from the USA, not only because this would preserve the lives of its soldiers, but mainly because it obviated the USA having to answer to any other nation or organisation for its techniques and practices. Given this, the US strategy could be summarised as distancing itself in physical and perceptual terms from the conflicts in question, mainly due to the use of drones and the mediation of information, thereby rupturing the reciprocity that characterises conventional warfare. Given its singular and unprecedented nature, growing numbers of scholars and other analysts have sought to analyse and theorise this development.

\section{Conclusion}

Many analysts have assessed Obama's presidency as one of the most efficient in terms of advancing international security, pointing to the same facts we have outlined above, notably the withdrawal of American troops from Iraq, as well as perceptions of improved stability in the Middle East. However, both of these two trophies of the Obama administration have come at increased costs, first in terms of using a controversial weapon that redefines the notion of conflict by distancing combatants from the battle, and second, in terms of fostering favourable media coverage about extrajudicial killings. This 'virtuous' strategy has allowed the USA to maintain a sustained extrajudicial killing campaign in the Middle East and North Africa, without major economic implications or political tribulations.

Political motivations have played a far greater role than economic ones in driving this far-reaching shift in military strategy. This has involved the realisation that the deployment of drones would guarantee 'riskless' operations for the combatants and consequently for the political decision-makers, allowing them to maintain high levels of attack during the past decade.

We have deviated from traditional theories to examine these movements and patterns, and demonstrate the importance of socio-political determinants of technology and its impacts on the structure of modern conflicts. This has allowed us to demonstrate that the distancing and ruptured reciprocity resulting from the use of drones were not accidental, but precisely predicted and desired. Moreover, it shows that contemporary US conflicts 
are extremely dependent on the narratives and conditioning created by the MiME-Net in several spheres.

In traditional Strategic Studies, advances in war technologies have always been presented as a positive phenomenon. Along the same lines, some neorealists have presented Cyber War, Network-Centric Warfare or at least Informational Warfare as legitimate means of addressing new forms of security threats (Klarke and Knake 2010).

By contrast, we have sought to show that technology cannot merely be understood as an 'asset' for military strategies, or an intensifier of the power of states. Instead, it modifies and redefines the strategies and logic of power by not only allowing more efficient tactics, but amplifying the range of political choices in a given conflict, and fundamentally altering political perceptions of how it is being waged.

When the USA uses drones against alleged insurgents in the Middle East, the conflict ceases to be a hard choice, and becomes an unpretentious and inconsequential political decision. Conflict then becomes a security resource capable of being invoked at any time, at a low cost, in any remote part of the planet. Waging a conflict, then, is not only a matter of continuing politics 'by other means'. Instead, the drone technology ensures that these 'means' become ordinary means in the quotidian course of politics.

\section{Notes}

1. For an analysis of the of a permanent state of violence, see the report Living Under Drones, developed by the NYU School of Law and the Stanford Law School. It contains strong evidence about the harassment and other traumas caused in other societies by these strikes perpetrated by the USA.

\section{References}

Ackerman, Spencer. 2014. '41 men targeted but 1,147 people killed: US drone strikes - the facts on the ground'. The Guardian [online], 24 November. At http://www.theguardian.com/us-news/2014/ nov/24/-sp-us-drone-strikes-kill-1147 [Accessed on 1 April 2016].

Almasmari, Hakim. 2012. 'Suspected U.S. drone strike kills civilians in Yemen, officials say'. CNN [online], 4 September. At http://edition.cnn.com/2012/09/03/world/meast/yemen-drone-strike/ [Accessed on 1 April 2016].

Belasco, Amy. 2014. The Cost of Iraq, Afghanistan, and other Global War on Terror Operations Since 9/11. Washington, DC: Congressional Research Service.

Bellamy, Christopher. 2001. 'What is information warfare?' In Ron Matthews and John Treddenick (eds), Managing the Revolution in Military Affairs. New York: Palgrave, pp. 56-75.

Brown, Alyssa and Frank Newport. 2013. 'In U.S. 65\% Support Drone Attacks on Terrorists Abroad'. Gallup [online], 25 March. At http://www.gallup.com/poll/161474/support-drone-attacks-terrorists-abroad.aspx [Accessed on 18 April 2016].

Buzan, Barry and Lene Hansen. 2009. The Evolution of International Security Studies. Cambridge: Cambridge University Press.

Cebrowsky, Arthur. 2000. 'Military responses to the informational age'. The RUSI Journal 145 (5): 25-29. 
Central Intelligence Agency (CIA). 2009. 'Director's Remarks at the Pacific Council on International Policy'. News \& Information [online], 18 May. At https://www.cia.gov/news-information/speechestestimony/directors-remarks-at-pacific-council.html [Accessed on 3 May 2016].

Chamayou, Grègoire. 2013. Théorie du Drone. Paris: La Fabrique.

Clarke, Richard A and Robert K Knake. 2010. Cyber War: The Next Threat to National Security and What to Do about It. New York: HarperCollins.

Congressional Budget Office. 2011. Policy Options for Unmanned Aircraft Systems. Washington, DC. Department of Defense (USA). 2012. Defense Budget Priorities and Choices. Washington, DC. At http://abcnews.go.com/images/Politics/Defense_Budget_Priorities_120126.pdf [Accessed on 17 July 2016].

2016. Operation Inhherent Resolve: Targeted Operations Against ISIL Terrorists. Washington, DC. At http://www.defense.gov/News/Special-Reports/0814_Inherent-Resolve [Accessed on 17 May 2016].

2010. Selected Acquisition Report (SAR). Washington, DC. At http://fas.org/man/eprint/F35-SAR.pdf [Accessed on 16 May 2016].

Department of State (USA). 2017. The Global Coalition to Counter ISIL. Washington, DC. At http:// www.state.gov/s/seci/index.htm [Accessed on 20 September 2017].

Der Derian, James. 2008. 'The Desert of Real and the Simulacrum of War'. International Affairs 84 (5): 931-948.

2009a. Critical Practices in International Theory: Selected Essays. New York: Routledge.

2009b. Virtuous War: Mapping the Military-Industrial-Media-Entertainment Network. New

York: Routledge.

Gray, Chris H. 1997. Postmodern War: The New Politics of Conflict. London: Routledge.

Hall, Abigail and Christopher Coyne. 2013. 'The political economy of drones'. Defense and Peace Economics 25 (5): 445-460.

Harrisson, Todd. 2013. Chaos and Uncertainty: The FY Defense Budget and Beyond. Washington, DC: CSBA.

Herring, George C. 2002. America's Longest War: The United States and Vietnam, 1950-1975. New York: McGraw-Hill.

International Human Rights and Conflict Resolution Clinic at Stanford Law School and Global Justice Clinic at NYU School of Law. 2012. Living under Drones: Death, Injury and Trauma to Civilians from US Drone Practices in Pakistan. New York.

Kaldor, Mary. 1999. 'The Weapons succession process'. In Donald Makenzie and Judy Wajcman (eds), The Social Shaping of Technology. Philadelphia: Open University Press, pp. 406-418.

Korte, Gregory. 2016. ' 16 times Obama said there would be no boots on the ground in Syria'. USA Today [online], 30 October. At http://www.usatoday.com/story/news/politics/onpolitics/2015/10/30/16times-obama-said-there-would-no-boots-ground-syria/74869884/ [Accessed on 1 May 2016].

Ministry of Defense (UK). 2014. 'UK Deploys Reaper to the Middle East. News Story'. London. At https://www.gov.uk/government/news/uk-deploys-reaper-to-the-middle-east [Accessed on 3 May 2016]. 
New America Foundation. 2016. Drone Wars Pakistan: Analysis. Washington, DC. At http://natsec. newamerica.net/drones/pakistan/analysis [Accessed on 12 April 2016].

O'Connel, Mary Ellen. 2011. 'Seductive drones: learning from a decade of lethal operations'. Journal of Law, Information \& Science 21 (2): 116-139.

Drones.pitchinteractive.com [online]. n.d. 'Out of sight, out of mind: a visualization of all documented drone strikes in Pakistan since 2004'. At http://drones.pitchinteractive.com/ [Accessed on 16 May 2014].

United Nations. 1979. Protocol Additional to the Geneva Conventions of 12 August 1949, and relating to the Protection of Victims of International Armed Conflicts (Protocol I), 7 December 1979.

Resende, Erica Simone Almeida. 2011. A crítica Pós-Moderna/Pós-Estruturalista nas Relações Internacionais. Boa Vista: Editora da UFRR.

Reuters [online]. 2012. 'U.S. drone kills five suspected militants in Yemen', 2 September. At http:// www.reuters.com/article/us-yemen-violence-idUSBRE88106S20120902 [Accessed on 1 April 2016].

Riopelle, Cameron and Parthiban Muniandy. 2013. 'Drones, maps and crescents: CBS News' visual construction of the Middle East'. Media, War \& Conflict 6 (2): 153-172.

Ullman, Harlan and James Wade. 1996. Shock and Awe: Achieving Rapid Dominance. Washington, DC: The National Defense University.

US Army. 2013. Joint Publication 1: Doctrine for the Armed Forces of the United States. Washington, DC.

Wendt, Alexander. 1999. Social Theory of International Politics. Cambridge: Cambridge University Press.

Whittle, Richard. 2014. Predator: The Secret Origins of the Drone Revolution. New York: Henry Holt and Company.

Williams, Bryan Glyn. 2010. 'The CIA’s covert Predator drone war in Pakistan, 2004-2010: The history of an assassination campaign'. Studies in Conflict \& Terrorism 33 (10): 871-892.

Winner, Langdon. 1980. 'Do artifacts have politics?' Deadalus 109 (1): 121-136.

Zenko, Micah and Amelia Wolf. 2016. Drones kill more civilians than pilots do. New York: Council on Foreign Relations.

\section{About the authors}

Alcides Eduardo dos Reis Peron is Professor of International Security and Contemporary Conflicts and Brazilian Political Institutions at Anhembi Morumbi University in Sao Paulo, Brazil. He holds degrees in International Affairs and Economics from Facamp (Faculdades de Campinas), and a Masters Degree and PhD in Science and Technology Policy from Campinas State University (UNICAMP), Brazil. Previously a visiting researcher at Lancaster University, he is a member of the Innovation Policy Analysis Group (GAPI) and Peace and Critical Security Studies Network. His main research interests are contemporary war, critical security studies, Science, Technology and Society (STS), and the politics of power, surveillance technologies, governmentality, militarism, and new technologies. 
Rafael de Brito Dias is Professor of Humanities and Applied Social Sciences at the School of Applied Sciences, Campinas State University (UNICAMP), Brazil, and holds a Masters Degree and PhD in Science and Technology Policy from the same university. He previously held a post-doctorate position at the Science and Technology Research Unit of Sussex University in the United Kingdom. He also holds a degree in Economics from Facamp (Faculdades de Campinas). He currently heads the Innovation Policy Analysis Group (GAPI) and Laboratory for Technology, Society and Democracy (LATESD) at Facamp. His main research interests include S\&T policy, technologies for social inclusion, and the political aspects of technologies.

\title{
'No Boots on the Ground': Reflexões sobre a Campanha de Drones dos Estados Unidos através das Teorias da Guerra Virtuosa e de STS
}

\begin{abstract}
Resumo: Desde 2004, a Força Aérea norte-americana e a Central Intelligence Agency (CIA) vêm perseguindo insurgentes na Somália, Iêmen e Paquistão com drones armados. Apesar da sua suposta eficiência, essa prática tem sido amplamente criticada com base no argumento de que ela contradiz o direito internacional humanitário. Para compreender as controvérsias relacionadas a essa prática, nós examinamos como essa nova tecnologia estava relacionada a e permitiu a emergência de uma nova estratégia de segurança dos Estados Unidos inicialmente aplicada no Oriente Médio. Inspirando-se nas teorias pós-estruturalistas de James Der Derian sobre as guerras virtuosas, a abordagem técnico-social permitida pelos Estudos da Ciência, Tecnologia e Sociedade (CTS), e pelas teorias de Gregoire Chamayou sobre drones, argumentamos que a intenção dos Estados Unidos ao adotar essas tecnologias não era a de aumentar a sua capacidade militar, mas se manter ativo em diversos cenários arriscados e, ao mesmo tempo, evitando os custos sociais e políticos do engajamento militar convencional.
\end{abstract}

Palavras-chave: Drones; Media; Guerra Virtuosa; Pós-estruturalismo; Estudos da Ciência, Tecnologia e Sociedade.

Received on 10 October 2016, and approved for publication on 4 July 2017. 